\title{
Comparative Study of Various Organic Fertilizers Effect on Growth and Yield of Two Economically Important Crops, Potato and Pea
}

\author{
Aisha Wazir¹, Zishan Gul2*, Manzoor Hussain'1 \\ ${ }^{1}$ Department of Botany, Faculty of Sciences, Hazara University, Mansehra, Pakistan \\ ${ }^{2}$ Hazara Agriculture Research Station, Abbottabad, Pakistan \\ Email: ^gul.zishan@gmail.com
}

How to cite this paper: Wazir, A., Gul, Z. and Hussain, M. (2018) Comparative Study of Various Organic Fertilizers Effect on Growth and Yield of Two Economically Important Crops, Potato and Pea. Agricultural Sciences, 9, 703-717.

https://doi.org/10.4236/as.2018.96049

Received: May 7, 2018

Accepted: June 22, 2018

Published: June 25, 2018

Copyright $\odot 2018$ by authors and Scientific Research Publishing Inc. This work is licensed under the Creative Commons Attribution International License (CC BY 4.0).

http://creativecommons.org/licenses/by/4.0/

(c) (i) Open Access

\begin{abstract}
In the present experiment, the effect of various house hold wastes i.e. T1 (egg shell powder), T2 (wood ash), T3 (banana peel), T4 (used tea waste), T5 (egg shell tea) and T6 (control) used as organic fertilizers on growth and yield of two important vegetables i.e. potato and pea was investigated. Among all the treatments, the minimum average number of days to germination was observed in T3 in both potato and pea. The overall growth and development of potato and pea plants increased and the average plant height after 30,60 and 90 days was greater in plants of treatment T1 (egg shell powder). In case of potato, the highest mean plant height $(14.75 \mathrm{~cm})$ was observed in treatment $\mathrm{T} 1$, followed by $\mathrm{T} 3$ and $\mathrm{T} 4(10.62 \mathrm{~cm}$ and $9.87 \mathrm{~cm})$ respectively after 90 days of the emergence. T1 treatment increases the no. of leaves, no. of nodes, no. of branches and leaf area. Regarding tuber yield, the tubers were classified as large ( $>30$ grams), medium ( $15-30$ grams) and small $(0.4-15$ grams). T1 treatment produced greater average number of large size tubers (2.25) per plant, followed by T3 (1.25); however, the medium and small tubers followed comparable trends with differences among treatments. The average tuber yield (per potato plant) in treatment T1 was higher (113.78 g). In case of pea, T4 treatment (used tea waste) showed the highest mean plant height (82.25 $\mathrm{cm}$ ). The treatment T1 (eggshell powder), T3 (banana peel) and T4 (used tea waste) showed positive effect on average pod yield $(64.82 \mathrm{~g}, 66.67 \mathrm{~g}$ and 114.35 g) respectively. Number of grains per pod and pod size has been found higher in case of treatment T4. It has been concluded that among the different organic treatments, eggshell powder, banana peel and used tea waste were found best as organic fertilizer source for the two vegetables i.e. potato and pea.
\end{abstract}

\section{Keywords}

Organic Fertilizers, Potato, Pea, Egg Shell, Banana Peel, Used Tea Waste 


\section{Introduction}

Agriculture was practiced for thousands of years without using any artificial chemicals. Soil management practices have recently increased the use of chemical fertilizers to help crop yields by improving nutrient supply. Use of these agrochemicals not only causes the degradation of cultivable land but also increases agricultural pollution. In order to overcome this situation, organic farming is the only solution in which only natural resources such as organic matter, plant and animal wastes and microbes are implied [1]. Use of organic manures has improved soil fertility and helps in combating pest and disease problems [2] [3] [4].

The use of homemade organic fertilizers is considered an environment friendly means to reduce the waste growing into landfill. Pakistani soil is deficient in organic matter than the recommendable level. 1.29\% carbon in soil is considered to be enough in organic matter, but most of the Pakistani soils have less than $1 \%[5]$.

Approximately 35 kinds of different vegetables are cultivated in numerous agro-ecological areas of Pakistan. Potato occupies the largest area (34.01\%) among vegetable production [6]. In Pakistan, the pea is also an important crop occupying 3rd position among the major leguminous crops [7] [8]. In Pakistan, the yield of potatoes and peas per hectare is very low as compared to advanced countries. Imbalance use of fertilizers is one of the major factor due to which production is declining continuously every year [9].

The major factor responsible for the rapid plant growth is the nutritional access in the soil. Deficiency of one nutrient in the soil may influence greatly the levels of other nutrients and their availability [10] [11].

The awareness of environment and food safety issues is responsible for the development of organic farming in the recent years [12] [13]. Eggshells wastes can be used as a plant fertilizer because eggshell contains $95 \%$ calcium carbonate and is potent source of lime [14] to neutralize the $\mathrm{pH}$ of acidic soil. A study demonstrated that plants of red clover when grown on eggshells fertilized soil grew $10 \mathrm{~mm}$ larger than the plants without eggshells [15]. Boiled Tea Waste (formed after making tea) is also used for correcting the $\mathrm{pH}$ of soil and is a good source of Tannic Acid which helps to neutralize the soil. Tea leaves contain potassium $(\mathrm{K})$, phosphorous $(\mathrm{P})$ and Nitrogen $(\mathrm{N})$, which are important elements for plant growth. When tea mixed with the soil, it improves the nutrient retention of the soil which can stimulate the plant growth.

Banana peels contain the three macronutrients i.e. Nitrogen, Phosphorus and Potassium, as well as many micronutrients, which promote the growth of garden plants from seed germination to blooms and fruits. Because of these nutrients, banana peels also help plants to resist against diseases [16]. Ash can be used for growing garden plants. The main constituents of ash are calcium, iron, magnesium, aluminum, potassium, sodium, silicone and titanium [17]. Insam et al. (2009) [18] found a progressive effect of ashes on soil texture, aeration, water 
holding capacity and cation exchange capacity. It is very alkaline in nature and can be used to increase the soil $\mathrm{pH}$.

Organic manuring is becoming an important part of environmentally sound sustainable agriculture. Residual nature of organic sources makes them more value based for the whole system as compared to individual crops [19]. Recently, farmers' choice is diverted to organic farming instead of chemical fertilizers because of their high cost and inefficiency to improve soil fertility [20]. Therefore, the purpose of present research was to evaluate the effect of different types of house hold waste as organic fertilizers on potato and pea plant growth and yield and an alternative utilization of house hold waste in an economically environment friendly manner.

\section{Material and Methods}

The present research work was conducted in the Green house at Hazara Agriculture Research Station, Abbottabad. Two important vegetables i.e. Potato (variety Kuroda) and Peas (variety Classic) were grown in pots of size $18 \times 20 \mathrm{~cm}$ filled with $4 \mathrm{~kg}$ of soil. There were six treatments for each vegetable and every treatment was replicated four times. In order to add almost equal amount (volume) of every organic fertilizer to the soil every treatment was applied as 3 tablespoons full because the amount of every treatment in terms of volume can be different if added on the basis of same weight as e.g. wood ash is less in weight as compared to egg shell powder so it results in a variety of varying quantities. The experiments were conducted using CRD experimental design. The data were analyzed by Analysis of Variance (ANOVA) and Least Significance Difference test was used for significance of results. All the statistical analyses were done using computer software Statistix 8.1.

\section{Experimental treatments}

\section{Eggshell Powder (T1)}

The eggshells were collected from household kitchen and bakery and dried in the shade, then grinded using household grinder. 3 tablespoons full (45 g) of eggshell powder per pot was added and mix well with the pot soil. Single seed of each vegetable i.e. potato and pea was planted per pot (Figure 1).

\section{Wood ash (T2)}

Wood ash is the remainder after combustion of wood and wood products (chips, Sawdust, bark etc.).Wood chips and sawdust was collected from furniture market and burned to make the ash. The wood ash was mixed with the pot soil @ 3 tablespoons full (11.7 g) per pot (Figure 1).

Banana peels (T3)

Banana peels were collected from house hold kitchen and fresh fruit juice shops. The peels were dried in sunlight and then shredded in to small pieces of size approximately $1 \mathrm{~cm}^{2} .3$ tablespoons full (20 g) of banana peel pieces were well mixed with pot soil.

Used Tea waste (T4) 

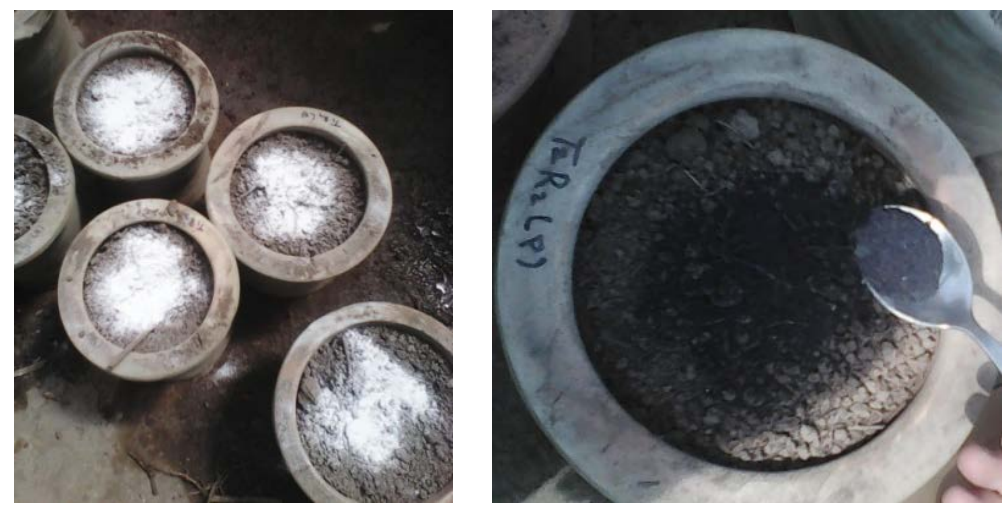

Figure 1. Addition of various treatments in pot soil.

The used tea waste was collected from household kitchens and local tea shops and dried in the shade then mixed with pot soil @ 3 tablespoons full $(15.9 \mathrm{~g})$ per pot.

\section{Eggshell Tea (T5)}

The eggshell tea was made by boiling 3 tablespoon full ( $45 \mathrm{~g}$ ) of crushed eggshell powder per liter of water for about one minute. The tea was allowed to cool and let it for 24 hours to release nutrients into the water more efficiently and then the supernatant was filtered in the bottle. The eggshell tea was used at the rate of $1000 \mathrm{ml}$ tea per pot.

\section{Control (T6)}

In the control treatment no organic fertilizer was mixed with the pot soil.

\section{Soil Analysis}

The pot soil from each treatment was analyzed to check its nutrient level. Soil sampling was done after about 60 days of applying different organic treatments in order to give enough time for proper decomposition and release of nutrients in to the pot soil before seed sowing. The soil samples were left for 3 days to dry properly. The soil $\mathrm{pH}$, Electrical conductivity, Total soluble salts (TSS), Nitrogen, Phosphorus, Potassium, Calcium, Magnesium, Carbonate, Bicarbonate was analyzed according to the analytical methods as described by [21].

\section{Results}

\section{Number of days to germination}

No significant difference in number of days to germination for both potato and pea was recorded in all the treatments including control. However, the treatment T3 (Banana peel) showed minimum average number of days to germination i.e. 7.75 for potato and 4.00 days for pea. The seedlings in case of treatment T6 (control) took maximum mean number of days for emergence, followed by treatment T2 (Table 1).

\section{Plant height}

The treatment $\mathrm{T} 1$ showed significantly highest mean plant height $(14.75 \mathrm{~cm})$ in potato plant (Table 2) after 90 days of seedling emergence followed by T3 
Table 1. Average number of days to germination of potato and pea seed.

\begin{tabular}{ccc}
\hline \multirow{2}{*}{ Treatments } & \multicolumn{2}{c}{ Av. no. of days to germination } \\
\cline { 2 - 3 } & Potato & Pea \\
\hline T1 & $8.50 \mathrm{a}$ & $5.00 \mathrm{a}$ \\
T2 & $9.50 \mathrm{a}$ & $7.00 \mathrm{a}$ \\
T3 & $7.75 \mathrm{a}$ & $4.00 \mathrm{a}$ \\
T4 & $8.00 \mathrm{a}$ & $4.75 \mathrm{a}$ \\
T5 & $9.50 \mathrm{a}$ & $5.00 \mathrm{a}$ \\
T6 & $9.75 \mathrm{a}$ & $7.25 \mathrm{a}$ \\
\hline
\end{tabular}

Different letters with each mean value in a column is significantly different at $\mathrm{P} \leq 0.05$.

Table 2. Effect of different organic fertilizers on various growth parameters after 90 days of emergence in potato plants.

\begin{tabular}{|c|c|c|c|c|c|c|}
\hline Treatments & $\begin{array}{c}\text { Average Plant } \\
\text { height }(\mathrm{cm})\end{array}$ & $\begin{array}{l}\text { Average no. of } \\
\text { leaves/plant }\end{array}$ & $\begin{array}{l}\text { Average no. of } \\
\text { leaves/branch }\end{array}$ & $\begin{array}{c}\text { Average no. } \\
\text { of nodes }\end{array}$ & $\begin{array}{l}\text { Average no. of } \\
\text { branches/plant }\end{array}$ & $\begin{array}{c}\text { Av. leaf } \\
\text { area }\left(\mathrm{cm}^{2}\right)\end{array}$ \\
\hline $\mathrm{T} 1$ & $14.75 \mathrm{a}$ & $72.00 \mathrm{a}$ & $7.22 \mathrm{a}$ & $11.50 \mathrm{a}$ & $13.50 \mathrm{a}$ & $14.85 \mathrm{a}$ \\
\hline $\mathrm{T} 2$ & $7.32 \mathrm{~b}$ & $48.00 \mathrm{~b}$ & $5.95 \mathrm{ab}$ & $6.50 \mathrm{~b}$ & $9.00 \mathrm{~b}$ & $9.26 b c$ \\
\hline T3 & $10.62 \mathrm{ab}$ & $66.00 \mathrm{ab}$ & $7.37 \mathrm{a}$ & $9.50 \mathrm{ab}$ & $12.00 \mathrm{ab}$ & $14.41 \mathrm{a}$ \\
\hline $\mathrm{T} 4$ & $9.87 \mathrm{~b}$ & $66.00 \mathrm{ab}$ & $7.00 \mathrm{a}$ & $9.00 \mathrm{ab}$ & $11.50 \mathrm{ab}$ & $12.93 \mathrm{ab}$ \\
\hline T5 & $9.25 \mathrm{~b}$ & $63.50 \mathrm{ab}$ & $6.80 \mathrm{ab}$ & $8.50 \mathrm{ab}$ & $11.00 \mathrm{ab}$ & $10.66 \mathrm{abc}$ \\
\hline T6 & $6.80 \mathrm{~b}$ & $45.50 \mathrm{~b}$ & $4.80 \mathrm{~b}$ & $6.50 \mathrm{~b}$ & $8.50 \mathrm{~b}$ & $7.45 c$ \\
\hline
\end{tabular}

Different letters with each mean value in a column is significantly different at $\mathrm{P} \leq 0.05$.

(banana peels) and T4 (used tea waste) in which the mean plant height is (10.62 $\mathrm{cm} ; 9.87 \mathrm{~cm})$ respectively. The lowest height $(6.80 \mathrm{~cm})$ was recorded in control treatment T6 (Table 2; Figure 2).

In case of Pea after 90 days of emergence the treatment T4 (used tea waste) showed the highest mean plant height $(76.25 \mathrm{~cm})$, followed by T3 and T1 (75.00; $71.50)$ respectively. The lowest plant height $(48.25 \mathrm{~cm})$ was recorded in control treatment T6 (Table 3; Figure 3).

\section{Number of Leaves per plant}

The data pertaining to numbers of leaves per plant for the treatments differed significantly in potato (Table 2 ). The treatment $\mathrm{T} 1$ showed greater mean no. of leaves (72.00). The treatments $\mathrm{T} 2$ and $\mathrm{T} 6$ showed significantly less number of leaves $(48.00,45.50)$, respectively per plant (Table 2 ). While in pea plant all the six treatments showed no significant difference (Table 3 ) in average leaf number per plant. However, the treatment T3 showed greater mean number of leaves per plant (79.00) and the treatments T5 and T6 showed significantly less number of leaves $(57.50 ; 55.00)$, respectively (Table 3 ).

\section{Average number of leaves per branch}

The data regarding the number of leaves per branch in potato (Table 2) revealed that significant difference was found in the number of leaves per branch 

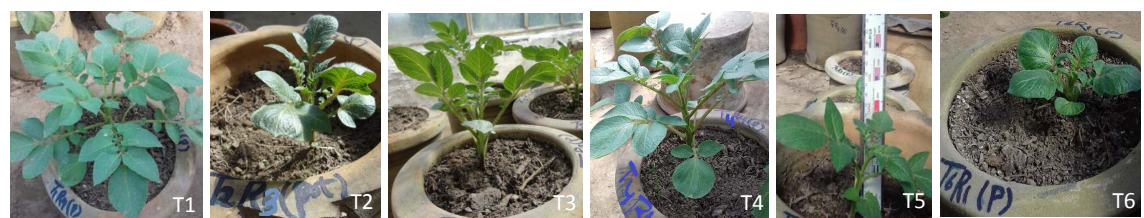

Figure 2. Growth of potato plants in various treatments i.e. T1 (Eggshell powder), T2 (Wood ash), T3 (Banana peel), T4 (used tea waste), T5 (Eggshell tea), T6 (Control).
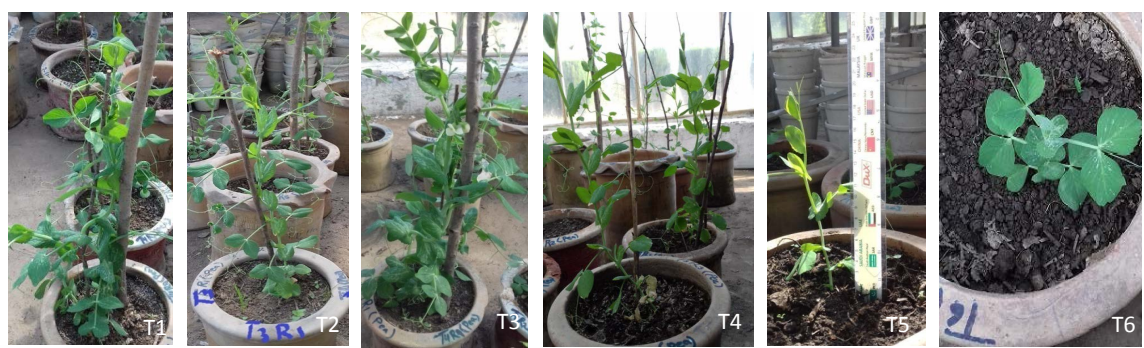

Figure 3. Growth of pea plants in various organic treatments i.e. T1 (Eggshell powder), T2 (Wood ash), T3 (Banana peel), T4 (used tea waste), T5 (Eggshell tea), T6 (Control).

Table 3. Effect of different organic fertilizers on various growth parameter of pea plant after 90 days of emergence.

\begin{tabular}{ccccccc}
\hline Treatments & $\begin{array}{c}\text { Plant } \\
\text { height }(\mathrm{cm})\end{array}$ & $\begin{array}{c}\text { No. of } \\
\text { leaves/plant }\end{array}$ & $\begin{array}{c}\text { Av. no. of } \\
\text { leaves/branch }\end{array}$ & $\begin{array}{c}\text { Av. no. of } \\
\text { nodes }\end{array}$ & $\begin{array}{c}\text { Av. no. of } \\
\text { branches/plant }\end{array}$ & $\begin{array}{c}\text { Av. leaf } \\
\text { area }\left(\mathrm{cm}^{2}\right)\end{array}$ \\
\hline T1 & $71.50 \mathrm{a}$ & $78.50 \mathrm{a}$ & $4.65 \mathrm{a}$ & $17.25 \mathrm{a}$ & $19.25 \mathrm{a}$ & $7.12 \mathrm{ab}$ \\
$\mathrm{T} 2$ & $67.00 \mathrm{a}$ & $66.50 \mathrm{a}$ & $3.90 \mathrm{a}$ & $15.50 \mathrm{a}$ & $17.00 \mathrm{a}$ & $6.29 \mathrm{a} \mathrm{b}$ \\
$\mathrm{T} 3$ & $75.00 \mathrm{a}$ & $79.00 \mathrm{a}$ & $5.30 \mathrm{a}$ & $17.00 \mathrm{a}$ & $19.00 \mathrm{a}$ & $7.66 \mathrm{ab}$ \\
$\mathrm{T} 4$ & $76.25 \mathrm{a}$ & $76.75 \mathrm{a}$ & $4.62 \mathrm{a}$ & $17.50 \mathrm{a}$ & $19.50 \mathrm{a}$ & $10.69 \mathrm{a}$ \\
$\mathrm{T} 5$ & $51.75 \mathrm{a}$ & $57.50 \mathrm{a}$ & $4.40 \mathrm{a}$ & $13.50 \mathrm{a}$ & $15.50 \mathrm{a}$ & $6.83 \mathrm{~b}$ \\
$\mathrm{~T} 6$ & $48.25 \mathrm{a}$ & $55.00 \mathrm{a}$ & $3.05 \mathrm{a}$ & $13.00 \mathrm{a}$ & $14.50 \mathrm{a}$ & $5.37 \mathrm{ab}$ \\
\hline
\end{tabular}

Different letters with each mean value in a column is significantly different at $\mathrm{P} \leq 0.05$.

among treatments. The highest mean number of leaves per branch was observed in the treatment T3 and T1which was 7.37 and 7.22 leaves per branch. Whereas in pea plant the treatment $\mathrm{T} 3$ showed higher mean leaves per branch i.e. 5.30 (Table 3).

\section{Number of nodes}

The data regarding the number of nodes in potato after 90 days of seedling emergence revealed that there is significant difference found among treatments (Table 2). The highest mean numbers of nodes were recorded in the treatment T1 which was 11.50 nodes per plant followed by treatment T3 in which 9.50 nodes were observed (Table 2), whereas the treatment $\mathrm{T} 2$ and T6 showed lowest number of nodes (6.5). While no significant difference found among treatments regarding average number of nodes in Pea. The treatment T4 has more nodes per plant (17.50) whereas treatment T6 showed less number of nodes per plant (13.00) (Table 3). 


\section{Number of branches per plant}

After 90 days of emergence the numbers of branches per plant in both potato and pea were recorded for all the treatments (Table $2 \&$ Table 3). Highest mean numbers of branches (13.50) were recorded in treatment $\mathrm{T} 1$ in potato while control treatment $\mathrm{T} 6$ showed lowest mean number of branches (8.50) which differed significantly (Table 2). In Pea plants after 90 days the treatment T4 (used tea waste) expressed highest mean number of branches per plant (19.50) (Table 3).

\section{Average leaf area}

Data regarding average leaf area of potato was presented in Table 2 showed significant difference $(\mathrm{P} \leq 0.05)$ in leaf area amongst treatments. The treatment T1 showed significantly highest average leaf area i.e. $14.85 \mathrm{~cm}^{2}$ followed by treatment T3 where the average leaf area was $14.41 \mathrm{~cm}^{2}$ as compared to control which showed lowest leaf area $\left(7.45 \mathrm{~cm}^{2}\right)$. In pea the highest average leaf area (Table 3) was recorded in T4 treatment $\left(10.69 \mathrm{~cm}^{2}\right)$ followed by treatment T3 where the average leaf area was $7.66 \mathrm{~cm}^{2}$. The treatment $\mathrm{T} 6$ showed lowest leaf area $\left(5.37 \mathrm{~cm}^{2}\right)$.

\section{Tuber Number}

The results showed that there are some significant differences $(\mathrm{P}<0.05)$ among different treatments with respect to the number of tubers produced per plant. Treatment T1 had the highest mean number of large and medium size tubers $(2.25 ; 1.25)$ respectively, while treatment $\mathrm{T} 5$ produced the highest mean number of small tubers (2.50) per plant (Table 4). It was noted that only the treatments $\mathrm{T} 1$ produced more number of large tubers while rest of the treatments including control produced greater number of small tubers (Table 4, Figure 4).

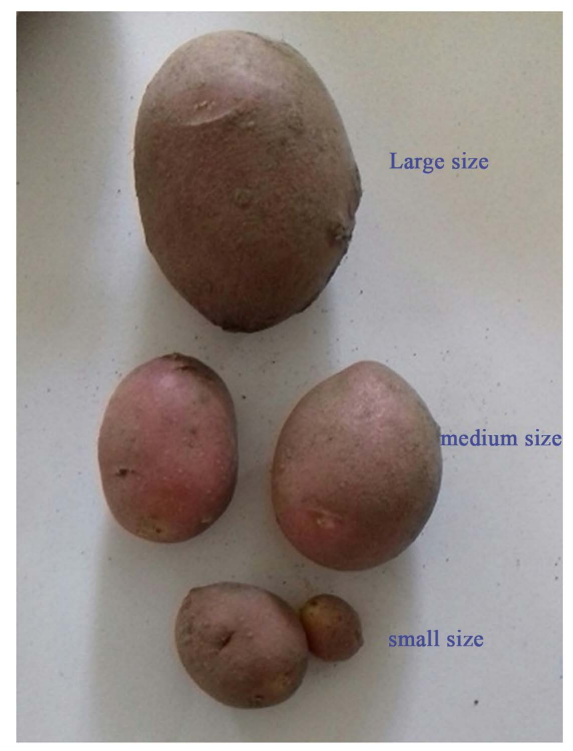

Figure 4. Tuber categories (large (>30 g), medium (15 - $30 \mathrm{~g}$ ), small (0.4 - $15 \mathrm{~g})$ on the basis of their weight. 
Table 4. Effect of different organic fertilizer treatments on potato tubers size and yield.

\begin{tabular}{|c|c|c|c|c|c|c|c|c|c|c|}
\hline \multirow[t]{2}{*}{ Treatments } & \multicolumn{3}{|c|}{$\begin{array}{l}\text { Mean tuber } \\
\text { no. per plant }\end{array}$} & \multicolumn{3}{|c|}{$\begin{array}{l}\text { Mean tuber weight } \\
\text { per plant (grams) }\end{array}$} & \multicolumn{3}{|c|}{$\begin{array}{l}\text { Average no. } \\
\text { of eyes per tuber }\end{array}$} & \multirow{2}{*}{$\begin{array}{c}\text { Total av. } \\
\text { tuber } \\
\text {-yield/plan } \\
\mathrm{t}(\mathrm{g})\end{array}$} \\
\hline & ${ }^{*}$ Large & ${ }^{\star}$ Medium & ${ }^{\star}$ Small & Large & Medium & Small & Large & Medium & Small & \\
\hline $\mathrm{T} 1$ & $2.25 \mathrm{a}$ & $1.25 \mathrm{a}$ & $1.75 \mathrm{a}$ & $75.22 \mathrm{a}$ & $27.95 a$ & $10.60 \mathrm{a}$ & $6.00 \mathrm{a}$ & $4.00 \mathrm{a}$ & $2.66 \mathrm{a}$ & $113.78 \mathrm{a}$ \\
\hline $\mathrm{T} 2$ & $0.50 \mathrm{~b}$ & $0.50 \mathrm{a}$ & $1.25 \mathrm{a}$ & $24.05 \mathrm{c}$ & $18.72 \mathrm{a}$ & $3.20 \mathrm{a}$ & $3.00 \mathrm{a}$ & $2.32 \mathrm{a}$ & $1.16 \mathrm{a}$ & $45.97 \mathrm{c}$ \\
\hline $\mathrm{T} 3$ & $1.25 \mathrm{~b}$ & $1.25 \mathrm{a}$ & $1.75 \mathrm{a}$ & $61.00 \mathrm{ab}$ & $31.27 \mathrm{a}$ & $10.01 \mathrm{a}$ & $5.87 \mathrm{a}$ & $3.50 \mathrm{a}$ & $2.75 \mathrm{a}$ & $102.34 \mathrm{ab}$ \\
\hline $\mathrm{T} 4$ & $1.00 \mathrm{~b}$ & $1.00 \mathrm{a}$ & $2.00 \mathrm{a}$ & $42.55 \mathrm{abc}$ & $24.15 a$ & $5.00 \mathrm{a}$ & $4.75 a$ & $3.25 \mathrm{a}$ & $2.40 \mathrm{a}$ & $71.7 \mathrm{bc}$ \\
\hline T5 & $0.75 b$ & $1.00 \mathrm{a}$ & $2.50 \mathrm{a}$ & $28.20 \mathrm{bc}$ & $23.32 \mathrm{a}$ & $8.52 \mathrm{a}$ & $4.65 a$ & $3.37 \mathrm{a}$ & $2.62 \mathrm{a}$ & $60.12 c$ \\
\hline T6 & $1.00 \mathrm{~b}$ & $0.50 \mathrm{a}$ & $2.00 \mathrm{a}$ & $34.00 \mathrm{bc}$ & $9.52 \mathrm{a}$ & $8.30 \mathrm{a}$ & $4.00 \mathrm{a}$ & $1.75 \mathrm{a}$ & $2.30 \mathrm{a}$ & $51.82 \mathrm{c}$ \\
\hline
\end{tabular}

Different letters with each mean value in a column is significantly different at $\mathrm{P} \leq 0.05$. ${ }^{*}$ Large size tubers: $>30$ grams, ${ }^{\star}$ Medium size: 15 - 30 grams, ${ }^{*}$ Small tubers: 0.4 - 15 grams.

\section{Tuber weight (grams)}

Regarding tubers weight for large, medium and small tubers categories, there is significant difference among treatments in case of weight of large tubers (Table 4). The treatment T1 had greatest mean weight of large tubers $(75.22 \mathrm{~g})$, followed by treatment T3 (61.00 g), however, the weight of medium and small tubers followed comparable trends with non-significant differences among treatments (Table 4, Figure 4).

\section{Average number of Eyes per tuber}

In case of average number of eyes per tuber, all the treatments showed no significant effect $(\mathrm{P} \geq 0.05)$ (Table 4). The data showed that the tubers in treatment $\mathrm{T} 1, \mathrm{~T} 3$ and T4 showed comparatively more eyes in case of all the three tubers categories i.e. Large, Medium and Small (Table 4).

\section{Total tubers yield (grams)}

A significant difference $(\mathrm{P}<0.05)$ is noted on the average tuber yield obtained per plant among different treatments. The treatment $\mathrm{T} 1$ showed significantly higher yield (113.78 g) (Table 4) followed by T3 in which the mean total yield is $102.34 \mathrm{~g}$. The lowest yield was recorded in treatment $\mathrm{T} 2$ and in control treatment T6 (45.97 g; $51.82 \mathrm{~g}$ ) respectively (Table 4).

\section{Pod Length}

The treatment T4 showed largest mean pod length i.e. $7.90 \mathrm{~cm}$ (Table 5). Whereas the small pods were formed in treatment $\mathrm{T} 2$ and $\mathrm{T} 6(5.56 \mathrm{~cm} ; 5.50 \mathrm{~cm})$ respectively (Table 5)

\section{Number of grains per pod}

The data regarding the number of grains per pod (Table 5) revealed that maximum average number of grains per pod was found in treatment T4 (6.16) while the minimum number of grain per pod was noted in control T6 (3.98).

\section{Number of pods per plant}

The data pertaining to number of pods per plant is an important character, which contributes considerably towards final yield. The treatment $\mathrm{T} 4$ showed 
Table 5. Effect of different organic fertilizer on various yield parameters of pea plant.

\begin{tabular}{cccccc}
\hline Treatments & $\begin{array}{c}\text { Pod length } \\
(\mathrm{cm})\end{array}$ & $\begin{array}{c}\text { Av. No. of } \\
\text { grain/pod }\end{array}$ & $\begin{array}{c}\text { Total } \\
\text { Pods/plant }\end{array}$ & $\begin{array}{c}\text { Single Pod } \\
\text { weight }(\mathrm{g})\end{array}$ & $\begin{array}{c}\text { Total } \\
\text { yield/plant }(\mathrm{g})\end{array}$ \\
\hline T1 & $7.39 \mathrm{a}$ & $4.64 \mathrm{a}$ & $16.50 \mathrm{a}$ & $3.80 \mathrm{a}$ & $64.82 \mathrm{a}$ \\
T2 & $5.56 \mathrm{a}$ & $4.11 \mathrm{a}$ & $14.25 \mathrm{a}$ & $3.42 \mathrm{a}$ & $56.05 \mathrm{a}$ \\
T3 & $7.27 \mathrm{a}$ & $4.72 \mathrm{a}$ & $18.00 \mathrm{a}$ & $4.22 \mathrm{a}$ & $66.67 \mathrm{a}$ \\
T4 & $7.90 \mathrm{a}$ & $6.16 \mathrm{a}$ & $24.50 \mathrm{a}$ & $5.10 \mathrm{a}$ & $114.35 \mathrm{a}$ \\
T5 & $6.96 \mathrm{a}$ & $4.61 \mathrm{a}$ & $15.00 \mathrm{a}$ & $3.75 \mathrm{a}$ & $64.35 \mathrm{a}$ \\
T6 & $5.50 \mathrm{a}$ & $3.98 \mathrm{a}$ & $12.00 \mathrm{a}$ & $3.11 \mathrm{a}$ & $46.17 \mathrm{a}$ \\
\hline
\end{tabular}

Different letters with each mean value in a column is significantly different at $\mathrm{P} \leq 0.05$.

maximum number of pods per plant (24.50) (Table 5) followed by T3 in which 18.00 pods per plant were recorded. Minimum number of pods per plant was found in treatment T2 and T6 treatments $(14.25 ; 12.00)$ respectively (Table 5).

\section{Single pod weight (g)}

The data on the single pod weight (Table 5) showed that the greatest single pod weight observed in treatment $\mathrm{T} 4(5.10 \mathrm{~g})$, whereas the treatment $\mathrm{T} 2$ and $\mathrm{T} 6$ showed lowest single pod weight (3.42 g; $3.11 \mathrm{~g}$ ) (Table 5).

\section{Total pod yield per plant}

No significant difference $(P \geq 0.05)$ has been noted in terms of total yield obtained per plant among different treatments. However, the treatment $\mathrm{T} 4$ showed higher yield (114.3 g) (Table 5) followed by T3 in which the mean total yield is $66.67 \mathrm{~g}$. The lowest yield was recorded in T6 treatment (46.17 g) (Table 5).

\section{Physico-chemical analysis of soil}

The data regarding the soil samples analysis for each treatment is presented in Table 6. Soil $\mathrm{pH}$ for the treatments falls in the alkalinity range with the lowest $\mathrm{pH}$ value (8.44) was observed in treatment $\mathrm{T} 6$ whereas the treatment $\mathrm{T} 2$ and $\mathrm{T} 3$ showed higher $\mathrm{pH}$ value $(8.95 ; 8.98)$ (Table 6).

The higher EC value and total soluble salts (T.S.S) was observed in control treatment T6 i.e. 5.36 and 3.43 respectively whereas minimum EC and T.S.S were in treatment $\mathrm{T} 3$ (1.14 and 0.72 ) respectively. The treatment $\mathrm{T} 4$ and $\mathrm{T} 3$ showed higher organic matter value i.e. 2.05 and 1.79\% respectively (Table 6). Soil N percentage was highest in treatment T4 $(0.10 \%)$. Whereas the treatment T3 showed highest phosphorous (18 ppm), potassium (88 ppm) and magnesium $\left(\mathrm{Mg}^{+}\right)(4.6 \mathrm{meq} / \mathrm{l})$, while in treatment $\mathrm{T} 1$ and $\mathrm{T} 5$ the $\mathrm{Ca}^{2+}$ (6; $\left.5.1 \mathrm{meq} / \mathrm{l}\right),\left(\mathrm{HCO}_{3}\right)$ $(2.4 ; 1.9 \mathrm{meq} / \mathrm{l}), \% \mathrm{CaCO}_{3}(38.5 ; 34.2)$ respectively, are found in higher quantities.

\section{Discussion}

Organic fertilizers are used to enhance soil quality and add nutrients essential for plant growth. In present research work soil is supplemented with different household organic waste as fertilizers for Potato (Solanum tuberosum L.) and Pea (Pisum sativum L.). Results revealed that treatment T3 (Banana peel) 
Table 6. Physico-chemical analysis of soil after 60 days of application of different organic treatments.

\begin{tabular}{ccccccc}
\hline \multirow{2}{*}{ Soil parameters } & \multicolumn{7}{c}{ Treatments } \\
\cline { 2 - 7 } & T1 & T2 & T3 & T4 & T5 & T6 \\
\hline PH & 8.86 & 8.95 & 8.98 & 8.69 & 8.72 & 8.44 \\
Electrical conductivity (E.C) \% & 2.30 & 1.40 & 1.14 & 2.99 & 1.54 & 5.36 \\
T.S.S & 1.47 & 0.89 & 0.72 & 1.91 & 0.98 & 3.43 \\
Organic matter \% & 1.70 & 1.53 & 1.79 & 2.05 & 0.34 & 0.67 \\
Nitrogen $(\mathrm{N}) \%$ & 0.06 & 0.07 & 0.08 & 0.10 & 0.05 & 0.03 \\
Phosphorus $(\mathrm{P}) \mathrm{ppm}$ & 16 & 13 & 18 & 17 & 14 & 10 \\
Potassium $(\mathrm{K}) \mathrm{ppm}$ & 78 & 82 & 88 & 80 & 78 & 68 \\
Calcium $\left(\mathrm{Ca}^{2+}\right) \mathrm{meq} / 1$ & 6 & 2 & 4 & 4 & 5.1 & 3 \\
Magnessium $\left(\mathrm{Mg}^{+}\right) \mathrm{meq} / 1$ & 3.5 & 2.4 & 4.6 & 3.9 & 3 & 2.2 \\
Bicarbonate $\left(\mathrm{HCO}_{3}\right) \mathrm{meq} / 1$ & 2.4 & 0.8 & 0.6 & 1 & 1.9 & 1.8 \\
Calcium carbonate $(\mathrm{CaCO}) \%$ & 38.5 & 35 & 33.3 & 32 & 34.2 & 20 \\
\hline
\end{tabular}

resulted in minimum average number of days to germination after seed sowing for both vegetables (Table 1). This is because Bananas peel is rich in minerals including potassium, phosphorus and calcium. Our results are in consistent with Patrick, (2017) [22]. Ascher et al. (1994) [23] reported that phosphorus plays a significant role in seed germination and viability. Soils having phosphorus deficiency oppressed the initial plant growth. Root growth has not only been increased by phosphorus but it also enhances plant's early maturity [24].

Regarding average plant height after 30,60 and 90 days it was observed that plants of treatment T1 (egg shell powder) has shown greater plant height in potato crop (Table 2). This may be due to the fact that eggshell is source of calcium and in the present research the treatment T1 (eggshell powder) increased the soil calcium level (Table 6). Kris, (2010) [25] reported that the water used to cook hard boiled eggs is a valuable source of calcium for growing vegetables. Our results are compatible with the findings of Nikose (2015) [26] who reported that eggshell along with Bio-waste when used in potted plants like money plant and wheat grass resulted a remarkable growth in the plant. Organic calcium not only helps to neutralize soils acidity [25] [27] but calcium is also a component of cell wall in plants, and it is needed for enzyme formation, nitrate uptake and root development. However, the plants of banana peel treatment showed rapid increase in growth in terms of plant height after 60 days of emergence. This may be due to the fact that banana peel was applied as small pieces and with the passage of time it released nutrients.

The data (Table $2 \&$ Table 3 ) showed that the number of leaves, number of nodes, number of branches per plant in both potato and pea is effected by using organic fertilizers which added calcium, potassium, phosphorus and nitrogen to 
the soil. The possible reason for this may be that the nitrogen helps in leaf growth, phosphorus promotes rooting, flowering, and fruit set, and $\mathrm{K}$ (potassium) is essential for stem and root growth and protein analysis. Potato plant roots absorb phosphorous in the form of phosphate from the soil. This phosphate moves up and down in the plant. Phosphorus deficiency in potato plants disturbs this transfer of $\mathrm{P}$ from older tissues to actively growing tissues. With prolonged deficiency, plants remained dwarf and have less leaf area. The effect of phosphorus added to the soil through banana peel treatment resulted in maximum number of pods per pea plant. Similar results regarding the effect of phosphorus on yield component have been reported in pea by [28] and in French bean [29] [30] [31] [32].

In our study, the use of used tea waste also had positive effect on the overall growth of pea plant (Table 3 ). Tea leaves contain potassium (K), phosphorous $(\mathrm{P})$, Nitrogen $(\mathrm{N})$ and Tannic acid, which are important nutrients for plant growth. The tea grounds when decompose increase soil nutrients which in turn promotes the activity of the beneficial microorganisms thus improve soil oxygenation, which strengthen the root system of plants. Used tea waste is a source of nitrogen [33] which plays a most important role in various physiological processes and our treatment T4 (used tea waste) also increased the soil nitrogen level (Table 6). Bloom, (2015) [34] reported that nitrogen encourages the uptake and utilization of other nutrients including potassium, phosphorous and controls overall growth of plant.

The average leaf area of the pea plant has also been higher in treatment T4 (used tea waste). The possible reason for this is reported by Ahmad et al. (2009) [35] that optimum rate of $\mathrm{N}$ increases photosynthetic processes and leaf area production and the maximum leaf area and total leaf biomass are a determinant of higher crop yield [36].

In the present study, the organic fertilizers effect on potato and pea yield presented in (Table 4 and Table 5) revealed that the treatments T1 (eggshell powder), T3 (banana peel), T4 (used tea waste) as compared to other treatments showed positive effect on yield. According to [37], the potassium increases crop yield and improves tuber quality. Cao and Tibbitts (1991) [38] indicated that low $\mathrm{K}$ not only decrease potato growth, but also disturb nutrient balance among major cations. The effect of organic fertilizers on potato tuber size presented in (Table 4) revealed that the treatment T1 (eggshell powder) showed larger tubers as compared to other treatments. It may be due to the fact that the eggshells add calcium to the soil (Table 6). Our results are in agreement with [39] who reported that calcium had a role at the time of tuber formation and its deficiency causes many plant abnormalities especially fruit and storage organs. Walker, and Csinos (1980) [40] reported that both potatoes and peanuts have underground storage organs and [41] found that calcium fertilization in peanuts can enhance peanut grade and yield. Our results for greater pea yield in treatment T4 (used tea waste) (Table 5) is may be due to increased soil $\mathrm{N}$ level (Table 6) and is also 
supported by the findings of [42] and [43] who were of the opinion that increased nitrogen fertilization had significant effect on yield and yield related characteristics in peas. In the present study the total yield as number of pods per plant, and number of grains per pod, pod size has also been found higher in treatment T4. Woyke, and Rzymowska (1986) [44] reported that pea yield is positively affected by increasing dose of nitrogen which facilitates vegetative growth and nodulation and increases green pod yield [45] and [46] [47].

\section{Conclusions and Recommendations}

The present study showed that different household organic fertilizers gave better growth and yield response in case of both potato and pea crops. The treatments T1 (Eggshell), T3 (Banana peel) and T4 (Used tea waste) not only increased plants growth but also had positive impact on yield in terms of number of tubers and pods per plant.

It is recommended that the use of these organic fertilizers in kitchen gardens is economically important where it not only replenishes soil organic matter but also gives the sustainable production. However, further research is needed under field conditions to collect waste materials like eggshells, fruit peels, tea waste from the industries and homes to know the effect of various organic household waste used as fertilizer on other plants especially vegetables and to evaluate their effects on plants when applied in larger quantities. There were certain limitations in the present research work regarding accurate measurement of quantities of various treatments, because the amount of every treatment in terms of volume can be different if added on equal weight basis, and some treatments are less in weight than others, thereby gaining more volume in bulk which results in a variety of different quantities for different treatments, so it is also recommended to standardize their quantities in terms of weight units for future studies and field applications.

\section{References}

[1] Ahmad, R., Jilani, G., Arshad, M., Zahir, Z.A. and Khalid, A. (2007) Bio-Conversion of Organic Wastes for Their Recycling in Agriculture: An Overview of Perspectives and Prospects. Annals of Microbiology, 57, 471-479.

https://doi.org/10.1007/BF03175343

[2] Abbasi, P.A., Al-Dahmani, J., Sahin, F., Hoitinkand, H.A.J. and Miller, S.A. (2002) Effect of Compost Amendments on Disease Severity and Yield of Tomato in Conventional and Organic Production Systems. Plant Disease, 86, 156-161. https://doi.org/10.1094/PDIS.2002.86.2.156

[3] Barker, A.V. and Bryson, G.M. (2006) Comparisons of Composts with Low or High Nutrient Status for Growth of Plants in Containers. Communications in Soil Science and Plant Analysis, 37, 1303-1319. https://doi.org/10.1080/00103620600626460

[4] Khadem, S.A., Galavi, M., Ramrodi, M., Mousavi, S.R., Rousta, M.J. and Moghadam, R.P. (2010) Effect of Animal Manure and Superabsorbent Polymer on Corn Leaf Relative Water Content, Cell Membrane Stability and Leaf Chlorophyll Con- 
tent under Dry Condition. Australian Journal of Crop Science, 4, 642-647.

[5] Azam, F. (2001) Legume-Bacterium (Rhizobium) Association-Symbiosis, a Marriage of Convenience, Necessary Evil or Bacterium Taken Hostage by the Legume. Pakistan Journal of Biological Sciences, 4, 757-761. https://doi.org/10.3923/pjbs.2001.757.761

[6] Ahmed, N., Hussain, N., Hussaink, K., Ahmed, I., El-Desuki, Salman, M.S.R., El-Nemr, M.A., Mubashir, M., Gillani, R.H. and Akram, M. (2004) An Overview of Soil Fertility and Salinity Status of Multan District. Indus Journal of Plant Sciences, 3, 311-316.

[7] Aslam, M., Mahmood, I.A., Sultan, T. and Ahmad, S. (2000) Inoculation Approach to Legume Crops and Their Production Assessment in Pakistan-A Review. Pakistan Journal of Biological Sciences, 3, 193-195. https://doi.org/10.3923/pjbs.2000.193.195

[8] Kazmi, R.M., Jeelani, G. and Bhatti, M.H. (2002) Studies on Yield of Some Promising Pea Cultivars against Powdery Mildew. National Integrated Pest Management Programe, NARC, Islamabad, Pakistan. Pakistan Journal of Agricultural Research, 17, 35-38.

[9] Pervez, M.A., Faqir, M. and Ehsan, U. (2000) Effect Organic and Inorganic Manures on Physical and Characteristic of Potato (Solanum tuberosum L.) International Journal of Agriculture and Biology, 2, 1-2.

[10] Jenkins, P.D. and Mahmood, S. (2003) Dry Matter Production and Partitioning in Potato Plants Subjected to Combined Deficiencies of Nitrogen, Phosphorus and Potassium. Ingentaconnect, 143, 105-112.

[11] Alva, A., Fan, M., Qing, C., Rosen, C. and Ren, H. (2011) Improving Nutrient-Use Efficiency in Chinese Potato Production: Experiences from the United States. Journal of Crop Improvement, 25, 46-85. https://doi.org/10.1080/15427528.2011.538465

[12] Worthington, V. (1998) Effect of Agricultural Methods on Nutritional Quality: A Comparison of Organic with Conventional Crops. Alternative Therapies in Health and Medicine, 4, 58-69.

[13] Masarirambi, M.T., Mduduzi, M.H., Olusegun, T.O. and Thokozile, E.S. (2010) Effects of Organic Fertilizers on Growth, Yield, Quality and Sensory Evaluation of Red Lettuce (Lactuca sativa L.) "Veneza Roxa". Agriculture and Biology Journal of North America, 1, 1319-1324. https://doi.org/10.5251/abjna.2010.1.6.1319.1324

[14] John, H. and Paul, K. (2006) Can Ground Eggshells Be Used as a Liming Source? Integrated Crop Management Conference, Iowa State University, 235-238.

[15] King'ori, A.M. (2011) A Review of the Uses of Poultry Eggshells and Shell Membranes. International Journal of Poultry Science, 10, 908-912. https://doi.org/10.3923/ijps.2011.908.912

[16] Kumar, K.P.S., Bhowmik, D., Duraivel, S. and Umadevi, M. (2012) Traditional and Medicinal Uses of Banana. Journal of Pharmacognosy and Phytochemistry, 1, 51.

[17] Kim, M.K., Shah, M.D., Islam, A., Yun, M.G., Kim, J.M. and Cho, J.J. (2011) Use of Bottom Ash of Waste Coal as an Effective Microbial Carrier. Bioscience, Biotechnology, and Biochemistry, 75, 2264-2268. https://doi.org/10.1271/bbb.110495

[18] Insam, H., Franke-Whittle, I.H., Knapp, B.A. and Plank, R. (2009) Use of Wood Ash and Anaerobic Sludge for Grassland Fertilization: Effects on Plants and Microbes. Bodenkultur, 60, 39-51.

[19] Arora, N. and Maini, P. (2011) Anaerobic Digested Slurry an Input for Sustainable Agriculture. Asian Journal of Experimental Sciences, 25, 59-62. 
[20] Oyedeji, S., Animasaun, D.A., Bello, A.A. and Agboola, A. (2014) Effect of NPK and Poultry Manure on Growth, Yield, and Proximate Composition of Three Amaranths. Journal of Botany, 2014, Article ID: 828750. https://doi.org/10.1155/2014/828750

[21] Gupta, P.K. (2004) Methods in Environmental Analysis: Water, Soil and Air. Agrobios Publishing, India, 408.

[22] Patrick, B. (2017) Using Banana Peels in the Garden Survival at Home. http://survivalathome.com/using-banana-peels-in-the-garden/

[23] Ascher, J.S., Graham, R.D., Elliott, D.E., Scott, M. and Jessop, R.S. (1994) Agronomic Value of Seed with High Nutrient Content. In: Saunder, D.A. and Hellel, G.P., Eds., Wheat in Heat-Stressed Environments. Irrigated, Dry Areas and Rice-Wheat Farming Systems, Cimmyt, Mexico, 297-308.

[24] Mullins, G.L., Bendfeldt, E.S. and Clark, R.A. (1996) Poultry Litter as a Fertilizer and Soil Amendment. Technical Publication No. 424-034, Virginia Cooperative Extension, Virginia State University, Blackburg, VA, USA.

[25] Kris (2010) Egg Shells in the Garden. https://www.baliadvertiser.biz/egg_shells/

[26] Nikose, H.S. (2015) Egg Shell and Bio-Waste Manure. International Journal of Scientific \& Engineering Research, 6, 1680-1685.

[27] Masley, S. (2016) Organic Calcium Sources for Gardens. https://www.Grow-it-Organically.com

[28] Srivastava, T.K. and Ahlawat, I.P.S. (1995) Response of Pea (Pisum sativum) to Phosphorus, Molybdenum and Biofertilizer. Indian Journal of Agronomy, 40, 630-635.

[29] Ahlawat, I.P.S. (1996) Response of French Bean (Phaseolus vulgaris) Varieties to Plant Density and Phosphorus Level. Journal of Agricultural Science, 66, 338-342.

[30] Kanaujia, S.P., Narayan, R. and Narayan, S. (1999) Effect of Phosphorus and Potassium on Growth, Yield and Quality of French Bean (Phaseolus vulgaris L.) cv. Contender. Vegetable Science, 26, 91-92.

[31] Parmar, D.K., Sharma, T.R., Saini, J.P. and Sharma, V. (1999) Response of French Bean (Phaseolus vulgaris) to Nitrogen and Phosphorus in Cold Desert Area of Himachal Pradesh. Indian Journal of Agronomy, 44, 787-790.

[32] Singh, R.V. (2000) Response of French Bean (Phaseolus vulgaris L.) to Plant Spacing, and Nitrogen and Phosphorus Fertilization. Indian Journal of Horticulture, 57, 338-341.

[33] Iannotti, M. (2017) Used Tea Leaves Make Great Soil. https://www.thespruce.com

[34] Bloom, A.J. (2015) The Increasing Importance of Distinguishing among Plant Nitrogen Sources. Current Opinion in Plant Biology, 25, 10-16. https://doi.org/10.1016/j.pbi.2015.03.002

[35] Ahmad, S., Ahmad, R., Ashraf, M.Y., Ashraf, M. and Waraich, E.A. (2009) Sunflower (Helianthus annuus L.) Response to Drought Stress at Germination and Seedling Growth Stages. Pakistan Journal of Botany, 41, 647-654.

[36] Rafiq, M.A., Ali, A., Malik, M.A. and Hussain, M. (2010) Effect of Fertilizer Levels and Plant Densities on Yield and Protein Contents of Autumn Planted Maize. Pakistan Journal of Agricultural Sciences, 47, 201-208.

[37] Anonymous. (1998) Potassium for Agriculture. Better Crops with Plant Food. Vol. 82, Potash \& Phosphate Institute (PPI), Norcross, GA, 40.

[38] Cao, W. and Tibbitts, T.W. (1991) Potassium Concentration Effect on Growth, Gas 
Exchange and Mineral Accumulation in Potatoes. Journal of Plant Nutrition, 14, 525-537. https://doi.org/10.1080/01904169109364222

[39] Irfan, U.H. (2005) Management of Potato (Solanum tuberosum L.) Fungal, Viral and Bacterial Diseases in Northern Areas by FSC and RD, MINFAL, MINKANAA and Agri. Dptt, Northern Areas, Gilgit, 30-53.

[40] Walker, M.E. and Csinos, A.S. (1980) Effect of Gypsum on Yield, Grade and Incidence of Pod Rot in Five Peanut Cultivars. Peanut Science, 7, 109-113. https://doi.org/10.3146/i0095-3679-7-2-13

[41] Coffelt, T.A. and Hallock, D.L. (1986) Soil Fertility Responses of Virginia Type Peanut Cultivars. Agronomy Journal, 78, 131-137. https://doi.org/10.2134/agronj1986.00021962007800010027x

[42] Lysenko, V.F. (1980) Effect of Top Dressing of Peas with Different Forms of Nitrogen Fertilizers on Productivity and Protein Synthesis. Field Crop Abstracts, 10, 908.

[43] Novikova, N.E., Lakhanov, A.P. and Gavrikova, A.A. (1986) The Role of Accumulation and Reutilization of Nutrients in Seed. Field Crop Abstracts, 1, 34.

[44] Woyke, H. and Rzymowska, R. (1986) Influence of Seed Treatment with Nitrogina on the Green Pea Seed Yield. Vegetable Crops Research Bulletin, 29, 31-45.

[45] Kanaujia, S.P., Rastogi, K.B. and Sharma, S.K. (1997) Effect of Phosphorus, Potassium and Rhizobium Inoculation on Growth, Yield and Quality of Pea cv. Lincoln. Vegetable Science, 24, 91-94.

[46] Kanaujia, S.P., Sharma, S.K. and Rastogi, K.B. (1998) Effect of Phosphorus, Potassium and Rhizobium Inoculation on Growth and Yield of Pea (Pisum sativum L.). Annals of Agricultural Sciences, 19, 219-221.

[47] Vorob, V.A. (2000) Effective Inoculation of Leguminous Plants in Relation to Provision of Phosphorus and Potassium and Dependence on rhizosphere Temperature. Agrokhimiya, 2, 42-44. 